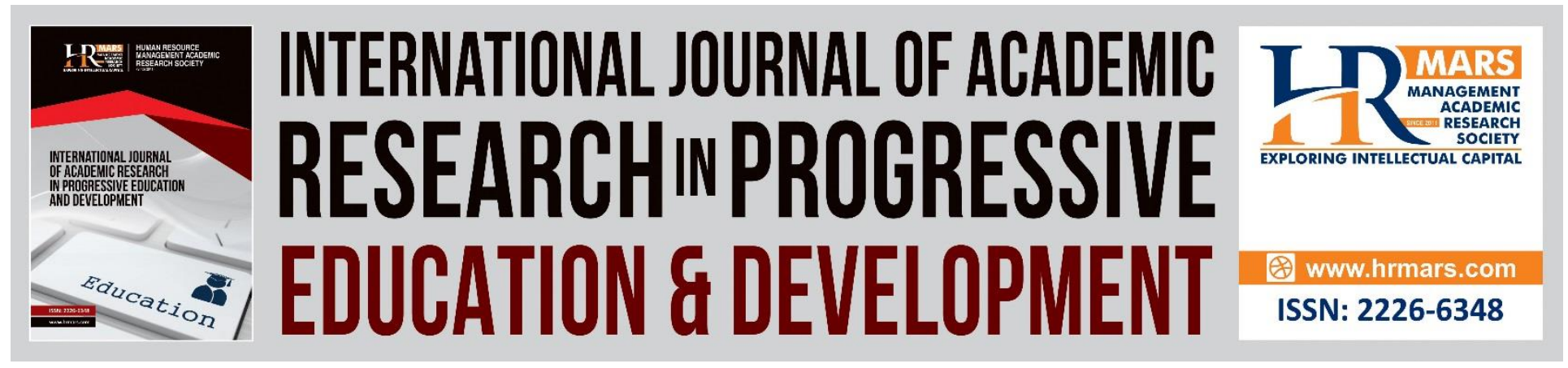

\title{
The Marketability of UiTM Products: A Study of Employability Skills Among UiTM Perlis Sports Graduates
}

\author{
Mohamad Firdaus Ahmad, Norlena Salamuddin, Shahlan Surat
}

To Link this Article: http://dx.doi.org/10.6007/IJARPED/v10-i1/8923

DOI:10.6007/IJARPED/v10-i1/8923

Received: 01 January 2021, Revised: 27 January 2021, Accepted: 17 February 2021

Published Online: 25 February 2021

In-Text Citation: (Ahmad et al., 2021)

To Cite this Article: Ahmad, M. F., Salamuddin, N., \& Surat, S. (2021). The Marketability of UiTM Products: A Study of Employability Skills Among UiTM Perlis Sports Graduates. International Journal of Academic Research in Progressive Education and Development, 10(1), 195-207.

Copyright: (c) 2021 The Author(s)

Published by Human Resource Management Academic Research Society (www.hrmars.com)

This article is published under the Creative Commons Attribution (CC BY 4.0) license. Anyone may reproduce, distribute, translate and create derivative works of this article (for both commercial and non-commercial purposes), subject to full attribution to the original publication and authors. The full terms of this license may be seen at: http://creativecommons.org/licences/by/4.0/legalcode

Vol. 10(1) 2021, Pg. 195 - 207

http://hrmars.com/index.php/pages/detail/IJARPED

JOURNAL HOMEPAGE

Full Terms \& Conditions of access and use can be found at http://hrmars.com/index.php/pages/detail/publication-ethics 


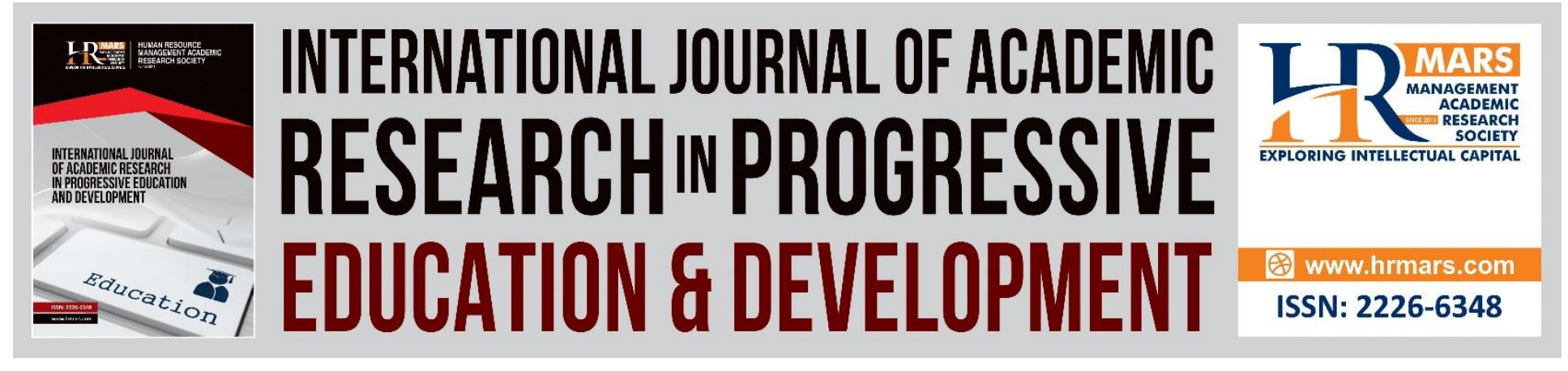

\title{
The Marketability of UiTM Products: A Study of Employability Skills Among UiTM Perlis Sports Graduates
}

\author{
Mohamad Firdaus Ahmad ${ }^{1,2}$, Norlena Salamuddin ${ }^{1}$, Shahlan \\ Surat ${ }^{1}$ \\ ${ }^{1}$ Faculty of Education, Universiti Kebangsaan Malaysia, ${ }^{2}$ Faculty of Sports Science and \\ Recreation, Universiti Teknologi MARA, Negeri Sembilan Branch, Seremban Campus \\ Email: firdaus466@uitm.edu.my, lena@ukm.edu.my,drshahlan@ukm.edu.my
}

\begin{abstract}
University students are expected to acquire the employability skills in order to meet the various demands and requirements of the market. The unemployment rate among graduates has become an issue, not only in Malaysia but has also become a global issue. This is because linear career path is something difficult to achieve as the modern career trajectory involves multidirection path. The main objectives of this study were to identify the main graduate employability skills and the perceptual difference of employability skills among UiTM Perlis sports graduates based on gender. This study was carried out on 335 sports graduates of UiTM Perlis Campus. The data were obtained through a questionnaire containing 55 items which was administered to measure the domains of graduate employability which covered areas such as problem solving and adaptability skills, human skills, English language proficiency and literacy skills, ICT skills, personal organization and time management skills, leadership skills and communication skills. The Cronbach Alpha reliability coefficient value of the instrument was 0.89 . The data were analyzed using inferential analysis (independent sample t-test). The findings showed that the communication skill was the main domain for the graduate employability skills and there was no significant difference in mean score for the employability skills based on gender for each domain $(p=0.00>0.05)$. Thus, understanding about employability skills among UiTM Perlis sports graduates may help to increase awareness among sports graduates in equipping themselves with the relevant skills that are needed in the working sector.
\end{abstract}

Keywords: Employability Skills, Sports Graduates, Sports Students, Working Skills

\section{Introduction}

Employability is a lifelong process that encourages students to develop a variety of knowledge, skills, behaviors and attitudes that enable them to succeed (Tanius, 2018). Employability skills are known as job readiness skills which refers to the vital skills in job security, 
including basic skills in reading, writing, arithmetic, reasoning and problem-solving (Azmi et al., 2018). In order to be involved in the working sector that can guarantee a good and stable job, graduates should possess these employability skills that are supposed to be developed during their study (Sumanasiri et al., 2015). Nowadays, many universities are producing a high number of graduates but the increasing amount of unemployment among Malaysian graduates is now a common scenario. For example, in 2010 , nearly 30,000 graduates were not able to be employed within the first six months after their graduation (Azmi et al., 2018). This is because graduates need to compete with other people in order to get a place in the working industry. Most of the graduates in this century will no longer have a linear career in one job, thus, the need to be prepared for changing job roles that may include freelance work and multiple occupations (Dinning, 2017). Besides that, they will also need to be prepared for working outside the sports industry, as research findings revealed a situation where there is a shortage of places in the industry which limit graduate's employability in this sector. According to a study conducted among UPSI students from the Faculty of Sports Science and Coaching (FSSK) showed the same problem of which the faculty decided that the students need to be educated and guided in preparing these students towards a challenging future (Hashim et al., 2019). There are seven domain that make up employability skills among graduates which are Problem Solving and Adaptability Skills, Humans Skills, English Language Proficiency and Literacy Skills, ICT Skills, Personal Organization and Time Management Skills, Leadership Skills and Communication Skills (Singh \& Singh, 2008). The main aim of this study is to investigate the main graduate employability skills as perceived by the UiTM Perlis sport graduates and the perceptual differences of employability skills among the male and female sport graduates of the same university.

\section{Literature Review}

Graduates are expected to be able to adapt in the working environment by improving their communication, critical thinking skills, decision-making and problem-solving, as well as the relevant analytical expertise that employers require (El Mansour \& Dean, 2016). One of the problems faced by university students is that they have been reported to be lack in various skills especially in problem solving and communication skills (Azmi et al., 2018). Besides that, when hiring employees, employers prefer to select candidates who are highly inspired, have basic skills and can adapt by using creative thinking and problem-solving skills to complete their tasks (Hani et al., 2017). This indicate that problem solving, and adaptability skills are one of the important skills highlighted by the employer. Shivoro et al. (2018) stated the criteria needed by the employers related to human skills such as learning ability and willingness, teamwork, strong interpersonal relationships, excellent customer service, efficiency, coordination and excellent performance to hire the employee. Human skills can be referred to soft skills such as interpersonal skill where the graduates show strong communication skills when dealing with people. According to Sarkar et al. (2016), employers from the UK's science and non-science sectors anticipated that graduates would have discipline-specific knowledge and skills but also expected that they would show a range of common skills and attributes like teamwork, communication, leadership, critical thinking, problem-solving and management skills. 
Furthermore, some university students were reported to lack in hard skills such as lack of technical expertise, difficulty applying information and low mastery of English communication skills (Azmi et al., 2018). Chan et al. (2018) define English proficiency as the capability of students to use English language to demonstrate and communicate in writing and speaking during the completion of the university studies. Previous study also showed that most fresh graduates lacked in employability skills, possess poor English language skills and communication skills, and have too many career choices. Besides that, high salary demand is also one of the main causes of unemployment among fresh graduates (Hossain et al., 2018). In the current development countries, graduates should get out of their comfort zone and need to try new things for them to get employed in any organization. Other than that, Information Technology (IT) refers to the use of technology in assisting tasks effectively (Shivoro et al., 2018) especially involving the ability to communicate and perform tasks using computer devices and applications. It is interesting to note that the perception of the information and communication technology (ICT) and the extent to which the use of technology was demonstrated in graduates played a significant role in contributing to the employability skills of the graduates (Tee et al., 2018). Both the course team and employers perceived that the use of technology was important and was extensively demonstrated by graduates.

Employers in private sector also consider personal organization and time management skills as necessary for for graduates (Ilhamie et al., 2018). According to Chan et al. (2018) there were several employability qualities that were rated higher by female respondents than by males, one of them being time management skills. The reason being is because of the current parental education and social strain, the different social roles and values for both sexes have been reinforced. Others include starting work on time, excitement, completing assigned tasks on time, competence, patience, efficiency, professional behavior and eagerness to learn and continue the career. The ethics of the work include the employee's attitude and character of the job. A research on the perceptions of higher education institutions created a list of attributes and characteristics of graduate employability including communication skills, initiative, independent work, imagination and problem solving, time management, networking, presentation skills, system thinking, self-confidence, enthusiasm, work ethics and leadership skills (Shivoro et al., 2018). Leadership skills refer to potential of individual to inspire others to accomplish organizational goals and positively influence team members. This is supported by Saidon (2017) who stated that a leader needs to be knowledgeable, profound, ability to effectively, visionary, competent, and always aware of current developments and issues lead an organization. In order to work in a team, graduates are supposed to deal with challenging situations occurring in the process of carrying out activities or may establish and lead individual or group activities.

The professional skills perceived by all stakeholders as one of the most significant characteristics for successful graduates was communication skills. Based on previous studies, the findings indicated that females fared relatively better on all skills, except for negotiating, planning, computer literacy and written communication (Ang, 2015). Other than that, they found that females are better than males in mastering most types of employability skills except for oral communication skills (El Mansour \& Dean, 2016). According to Ang (2015), a recent graduate 
employability study conducted by KDU University College in Kuala Lumpur found that $60 \%$ of employers said they did not hire due to poor communication skill. Besides that, previous studies revealed that graduates reported that communication skills, planning skills and knowledge of ethical and social issues were among the significant gaps between the qualities they learned from their degree in undergraduate science and what they saw as necessary for their work (Sarkar et al., 2016).

Thus, employability skills could be described as essential job-security skills, including basic reading, writing, arithmetic and thinking skills and problem-solving skills. In order to be recruited, graduates must possess certain skills or competencies. Besides that, there are sources categorized as employability by competency areas which are personal value, problem-solving and decision-making skills, maturity, health and safety habits and commitment to job (Azmi et al., 2018). The literature listed out the main critical gap including applied or technical skills, interpersonal skill and 21st-century skills. They were mainly in critical or analytical thinking, oral communication, active listening, prioritization and focus as well as time management (Tanius, 2018). However, there are still some countries which face economic and financial crises, that can affect the value of the inventories in this field resulting in the graduates to be selected based on those with high qualifications only. Furthermore, marketability is related to the ability of graduates to work and the readiness of graduates to work, and not merely to gain merit.

\section{Problem Statement}

Youth under the age of 25 are facing challenges in employment while the graduate job market faces increasing political and socioeconomic pressures. Unemployment among graduates has become an issue, not only in Malaysia, but also worldwide (Hanafi \& Nordin, 2014). Mishra (2014) stated that there are many universities in the country whereas the number of positions offered in the work sector is small and cannot accommodate or fulfill the number of graduates. This situation has led to the unemployment rate among internally displaced Malaysians while employment is still opened for hiring new workers (Hanafi \& Nordin, 2014). Furthermore, Hamid and Manaf (2013) found that low performance in carrying out job assignments was due to the graduates lacking in work skills causing them to be unemployed. This indicates that unemployment is not only due to lack of job opportunities, but also due to other factors such as low-quality graduates in carrying out assignments given by employers (Hanafi \& Nordin, 2014). It is the role of the higher education institutions to complement students not only with specific specifications, but most importantly is to prepare graduates with the required work skills. Most of graduates left their university without getting the skills that required by employers. However, a wider range of career opportunities are available for graduates who have bachelor in sports program (Fleming et al., 2009). Many sports graduates do not obtain work within the sport sector, instead, they are entering a wider range of occupations due to individual aspiration, opportunity, and structure of the industry (Minten \& Forsyth, 2014). According to Baker et al. (2017), sport graduate skills that are specifically made to cater for the sport industry are therefore likely to obtain employment following the completion of their study. 
There is a need to understand further on the types of skills and career development pathways in this sports sector. According to Tomlinson (2018) it is important for graduates to see the need to increase personal value and professionalism related to the job while knowing about the challenges in the increasingly competitive job market so that the marketability of these graduates become the main focus and goal in the university. In this case, Universiti Teknologi MARA (UiTM) is a comprehensive university that houses more than 165,000 students and has the highest number of IPT students in Malaysia has shown a high level of marketability of UiTM graduates when the reputation of employers increased by 55.7 marks in 2018 compared to 44.8 marks for 2017, thus placing UiTM at 82nd position in Asia compared to 114th for 2017 (Md Zain, 2017). UiTM has also produced many sports graduates every year in line with the demand of the sports industry in Malaysia. According to Amla (2010), prospective employers always give priority to graduates with soft skills and manpower skills that are closely related to the marketability of graduates. Graduates who lack skills such as communication, low English proficiency, lack of motivation and social skills cause them to not have a good self-appearance. Therefore, the purpose of the study is to identify the main graduates' employability skills as perceived by UiTM Perlis sports graduates and to determine the difference perception of employability skills among UiTM Perlis sports graduates based on gender.

\section{Methodology}

The population of sport graduates from UiTM Perlis is the focus of this scientific query. Simple random sampling was used in this study as it allowed exploration and investigation of the difference perception of UiTM Perlis sport graduates. The sample size of this research is $\mathrm{N}=335$ respondents. Out of 335 respondents, 192 (57.3\%) were female and 143 (42.7\%) were male. Items from an instrument of questionnaire were adopted and adapted from previous research done by Singh and Singh (2008) and were applied in order to know what are the main employability skills as perceived by UiTM Perlis sport graduates and to investigate the difference in perception of UiTM Perlis sport graduates based on the gender. The questionnaire consists of two sections whereby section A presents the demographic background and section $B$ includes the domains that make up employability skills, represented by 55 items. All the items in section $\mathrm{B}$ were rated on a 5-point-Likert Scale format ranging from 1 (strongly disagree) to 5 (strongly agree).

In this research, the researcher used Statistical Package for Social Sciences (SPSS) to analyze the data. The data from the pilot study were analyzed for its reliability values. The overall reliability for all domain showed above the 0.60 value set by the researcher. Konting (2005) suggested that the measurement of reliability using Cronbach Alpha coefficient at level 0.6 and above is as Alpha value with high reliability. After the pilot study was conducted, the research was conducted onto the actual sample. A normality test is used to test if the data is normally distributed. Based on the result, the researcher chose to proceed in analyzing the data using parametric testing. In conducting the first objective of this study, table 1 present a descriptive statistical analysis was used to identify the preferred employability skills among UiTM Perlis sport graduates while an Independent T-test was used to fulfil the second objective which was to 
INTERNATIONAL JOURNAL OF ACADEMIC RESEARCH IN PROGRESSIVE EDUCATION AND

DEVELOPMENT

Vol. 10, No. 1, 2021, E-ISSN: 2226-6348 @ 2021 HRMARS

identify the differences in perception of employability skills among female and male graduates of the same sample.

Table 1 Specification of Measurement Scale and Data Analysis Procedure

\begin{tabular}{|c|c|c|c|c|}
\hline Section & Details of Measurement & $\begin{array}{c}\text { Number of } \\
\text { Items }\end{array}$ & $\begin{array}{c}\text { Cronbach } \\
\text { Alpha }\end{array}$ & $\begin{array}{c}\text { Statistic } \\
\text { Procedure }\end{array}$ \\
\hline A & Demographic Profile & $1-2$ (2 Items) & & Descriptive \\
\hline \multirow[t]{10}{*}{ B } & Employability Skills Domain & & & \\
\hline & - Problem Solving and Adaptability Skills & 1-19 (19 Items) & .746 & \\
\hline & - Human Skills & $20-29(10$ & .764 & \\
\hline & - English Language and Proficiency Skills & Items) & .779 & \\
\hline & - ICT Skills & 30-35 (6 Items) & .674 & Independen \\
\hline & - Personal Organizationand & $36-40$ (5 Items) & .853 & $\mathrm{t}$ \\
\hline & Management & 41-47 (7 Items) & & T-test \\
\hline & Skills & & .814 & \\
\hline & - Leadership Skills & 48-52 (5 Items) & .832 & \\
\hline & - Communication Skills & 53-55 (3 Items) & & \\
\hline
\end{tabular}

\section{Findings}

Table 2 and Table 3 present the mean scores and standard deviation for the domains of employability skills. This was done to answer the first and second research questions which focus on the main graduate employability skills perceived by UiTM Perlis sports graduates and the perceptual differences between the two genders. Based on table 2, it is found that the main domain of the employability skills among UiTM Perlis sports graduate is Communication Skills where the mean values of 4.31 and the lowest domain is Problem Solving and Adaptability Skills domain with the mean values of 4.19 .

Based on Table 3, the result shows that there is no significant difference in perception of UiTM Perlis sports graduate based on gender regarding the employability skills. A further breakdown of the domain show these findings; "Problem Solving and Adaptability Skills", $t(332)$ $=-.649, \mathrm{p}=.517$, "Human Skills", $\mathrm{t}(332)=-.779, \mathrm{p}=.437$, "English Language Proficiency and Literacy Skills" $\mathrm{t}(332)=.55, \mathrm{p}=.582$, “ICT Skills", $\mathrm{t}(332)=-.46, \mathrm{p}=.644$, "Personal Organization and Time Management Skills" $\mathrm{t}(332)=.939, \mathrm{p}=.348$," Leadership Skills", $\mathrm{t}(332)=.068, \mathrm{p}=.946$ and "Communication Skills", $t(332)=.90, p=.366$. Hence, the results indicate that all the seven domains which are Problem Solving and Adaptability Skills, Human Skills, English Language Proficiency and Literacy Skills, ICT Skills, Personal Organization and Time Management Skills, Leadership Skills and Communication Skills have no significance value of perception based on gender. 
INTERNATIONAL JOURNAL OF ACADEMIC RESEARCH IN PROGRESSIVE EDUCATION AND DEVELOPMENT

Vol. 10, No. 1, 2021, E-ISSN: 2226-6348 @ 2021 HRMARS

Table 2 Descriptive Statistics of Employability Skills

\begin{tabular}{lcc}
\hline & Mean & SD \\
\hline Problem Solving and Adaptability Skills & 4.1934 & .34464 \\
Human Skills & 4.2218 & .36637 \\
English Language Proficiency and Literacy & 4.2134 & .43865 \\
Skills & & \\
ICT Skills & 4.2543 & .43668 \\
Personal Organization and Time & 4.2584 & .44807 \\
Management Skills & & \\
Leaderships Skills & 4.2663 & .44858 \\
Communication Skills & 4.3124 & .53041 \\
\hline
\end{tabular}


INTERNATIONAL JOURNAL OF ACADEMIC RESEARCH IN PROGRESSIVE EDUCATION AND DEVELOPMENT

Vol. 10, No. 1, 2021, E-ISSN: 2226-6348 @ 2021 HRMARS

Table 3 Difference Perception of Employability Skills Based on Gender

\begin{tabular}{|c|c|c|c|c|c|c|}
\hline & $\begin{array}{l}\text { Gende } \\
r\end{array}$ & $\mathrm{~N}$ & Mean & $\begin{array}{l}\text { Std. } \\
\text { Deviation }\end{array}$ & $\begin{array}{l}\text { Std. Error } \\
\text { Mean }\end{array}$ & $\begin{array}{l}\text { Sig. (2- } \\
\text { tailed) }\end{array}$ \\
\hline \multirow[t]{2}{*}{$\begin{array}{l}\text { Problem Solving and } \\
\text { Adaptability Skills }\end{array}$} & $\begin{array}{l}\text { Femal } \\
\mathrm{e}\end{array}$ & 192 & 4.1828 & .34464 & .02487 & .52 \\
\hline & Male & 143 & 4.2076 & .34534 & .02888 & \\
\hline \multirow[t]{2}{*}{ Human Skills } & $\begin{array}{l}\text { Femal } \\
\mathrm{e}\end{array}$ & 192 & 4.2083 & .36140 & .02608 & .44 \\
\hline & Male & 143 & 4.2399 & .37344 & .03123 & \\
\hline \multirow{2}{*}{$\begin{array}{l}\text { English Language } \\
\text { Proficiency and Literacy } \\
\text { Skills }\end{array}$} & $\begin{array}{l}\text { Femal } \\
\mathrm{e}\end{array}$ & 192 & 4.2248 & .42733 & .03084 & .58 \\
\hline & Male & 143 & 4.1981 & .45448 & .03801 & \\
\hline \multirow[t]{2}{*}{ ICT Skills } & $\begin{array}{l}\text { Femal } \\
\mathrm{e}\end{array}$ & 192 & 4.2448 & .42324 & .03054 & .64 \\
\hline & Male & 143 & 4.2671 & .45529 & .03807 & \\
\hline \multirow{2}{*}{$\begin{array}{l}\text { Personal Organization } \\
\text { and Time Management } \\
\text { Skills }\end{array}$} & $\begin{array}{l}\text { Femal } \\
\mathrm{e}\end{array}$ & 192 & 4.2783 & .45169 & .03260 & .35 \\
\hline & Male & 143 & 4.2318 & .44334 & .03707 & \\
\hline \multirow[t]{2}{*}{ Leaderships Skills } & $\begin{array}{l}\text { Femal } \\
\mathrm{e}\end{array}$ & 192 & 4.2677 & .45233 & .03264 & .95 \\
\hline & Male & 143 & 4.2643 & .44507 & .03722 & \\
\hline \multirow[t]{2}{*}{ Communication Skills } & $\begin{array}{l}\text { Femal } \\
\mathrm{e}\end{array}$ & 192 & 4.3351 & .53226 & .03841 & .37 \\
\hline & Male & 143 & 4.2821 & .52824 & .04417 & \\
\hline
\end{tabular}

\section{Discussions}

Employability skills are defined as the skills that required to achieve one's potential and contribute excellently to a more strategic and robust direction, and not merely the skills needed to gain a job (Australia, 2004). The main goal when students completed their studies is to find and secure a job. They should use their advantages to attract any organization or company to hire them. Therefore, every graduate should be able to identify their employability skills that are 
needed when finding a job. Based on previous research, it is found that the main domain for graduates around Klang who have earned a job is Problem Solving and Adaptability Skills (Singh \& Singh, 2008). Meanwhile for this study, sport graduates from UiTM Perlis result showed that communication skills as a domain is the highest while problem solving and adaptability skills is the lowest domain. This shows that sports graduates from UiTM Perlis Campus have good communication skills in terms of making good presentations, can form good logical arguments to persuade others and are able to express ideas verbally individually or in groups. Besides that, this research also found that problem solving, and adaptability skills are the lowest domain mean value among other skills.

The findings of this research showed that there is no significant difference between gender regarding employability skills for all domain when the $p$-value is more than 0.05. Communication Skills was the highest domain with a mean value for female sports graduates is 4.33 and the male sports graduates is 4.28 . This means that the level of communication skills of female sports graduates is better than male sports graduates. This is because female students feel more confident and are not feel shy when they use English language when communicating with others. The better the English language is, the more often someone uses the language (Latif \& Hanifah, 2008). However, the findings of this study contradict with previous findings done by El Mansour and Dean (2016) which found that females place a stronger emphasis than males on most types of employability skills except for oral communication skills. According to Mustapha (2015), the shyness of speaking in English was detected as one of the main causes of students having poor command of the language. According to Walqui (2000), having the interest towards the second language will contribute the person to learn English with better and effective impacts. Therefore, the difference in the level of communication skills among sports graduates is due to the feeling of shy and the lack of interest among male graduates in using English in their daily routine as compared to female graduates.

Based on the results, problem solving and adaptability skills was the lowest domain with a mean value of 4.24 for male which is higher than female with 4.20 . This result is supported by previous study done by Aliakbari and Sadeghdaghighi (2011) which found female to have gain low critical thinking skill compared to male. Problem-solving skills and critical thinking are important for the higher education institutions to prepare their graduates with the necessary approvals for successful employment (Singh et al., 2013). However, this result rejects past research finding that females have high problem solving and adaptability skills compared to males. As found by Tartre (1993), male had lower spatial orientation skills than female in integrating spatial and language skills when conducting problem solving situations.

In conclusion, understanding the employability skills among UiTM Perlis sports graduates will help the related organization and parties to plan necessary strategies to enhance the student's employability skills or generic skills before they graduate and ready for the working world. The result of this study indicated that communication skills was the main important domain among all when it comes to the employability skills of sports graduates in being hired in working in the necessary field. Finally, researcher in this study would recommend the future 
researcher to explore and understand sports graduate's employability skills from another universities in Malaysia.

\section{Contributions of the Research}

The findings of this study contribute to the various issues and clarification derived from the literature review. Firstly, the findings provide further insight and understanding on the matter of employability among sport graduates in Malaysia. This will allow future researchers to expand their research objectives into other aspects with regards to sport graduates and employability, in ensuring a continuous addition of data from previous studies. Thus, this study can be deemed as a useful added value to subsequent studies related to the employability of graduates in sports. Secondly, this study can be used as reference and guidelines among employers from the government and private sectors especially in identifying and selecting qualified employees in the sports background as the findings allows an insight on the priority skills that sports graduates possessed which may be of interested to them. Furthermore, this study can be helpful to the management level of the faculty and university as it provides significant impact in ensuring that good quality graduates would be continuously produced to ensure a high employability rate in Malaysia. Therefore, the university can plan and enhance their learning syllabus in accordance with the demand of the job market, thus improving the skills of their sports graduates to meet the requirements of their future employers.

\section{References}

Aliakbari, M., \& Sadeghdaghighi, A. (2011). Investigation of the relationship between gender, field of study, and critical thinking skill: the case of Iranian students. In Proceedings of the 16th Conference of Pan-Pacific Association of Applied Linguistics (pp. 14-26).

Amla, M. S. (2010). Pendidikan kerjaya dan pembangunan modal insan. Bangi: Penerbit Universiti Kebangsaan Malaysia and managerial implications. Research in Personnel and Human Resource Management, 16, G.R. Ferris (ed). Greenwich, and prospects. Academy of Management Journal, 39, 779-801.

Ang, M. C. (2015). Graduate employability awareness: a gendered perspective. Procedia-Social and Behavioral Sciences, 211, 192-198.

Australia. Department of Education, Science and Training (DEST) Allen Consulting Group; National Centre for Vocational Education Research (NCVER). (2004). Employability skills: final report: development of a strategy to support the universal recognition and recording of employability skills, a skills portfolio approach, December 2004. DEST, Canberra, Australian Capital Territory.

Azmi, I. A. G., Hashim, R. C., \& Yusoff, Y. M. (2018). The employability skills of Malaysian university students. International Journal of Modern Trends in Social Sciences, 1(3), 1-14.

Baker, C., Loughren, E. A., Dickson, T., Goudas, M., Crone, D., Kudlacek, M., \& Benoit, A. (2017). Sports graduate capabilities and competencies: a comparison of graduate and employer perceptions in six EU countries. European Journal for Sport and Society, 14(2), 95-116.

Chan, S. W., Ahmad, M. F., Zaman, I., \& Ko, W. S. (2018). Employers' perception on important employablity skills in the manufacturing industry. International Journal of Engineering \& Technology, 7(2.29), 170-175. 
Dinning, T. (2017). Embedding employability and enterprise skills in sport degrees through a focused work-based project; a student and employer viewpoint. Cogent Education, 4(1), 1387085.

El Mansour, B., \& Dean, J. C. (2016). Employability skills as perceived by employers and university faculty in the fields of human resource development (HRD) for entry level graduate jobs. Journal of Human Resource and Sustainability Studies, 4(01), 39.

Fleming, J., Martin, A. J., Hughes, H., \& Zinn, C. (2009). Maximizing work-integrated learning experiences through identifying graduate competencies for employability: A case study of sport studies in higher education. International Journal of Work-Integrated Learning, 10(3), 189.

Hamid, M. S. A., Islam, R., \& Manaf, N. H. (2013). Enhancing Malaysian graduate employability skills: Quality function deployment approach. In the International Symposium on the Analytic Hierarchy Process.

Hanapi, Z., \& Nordin, M. S. (2014). Unemployment among Malaysia graduates: Graduates' attributes, lecturers' competency and quality of education. Procedia-Social and Behavioral Sciences, 112, 1056- 1063.

Hani, M. Y., Rudzi, M., Shafini, N. M. S., Rapidah, S. O. A., \& Amin, S. M. (2017). Employers Perspectives on Graduates Employability Skills: Soft Skills. Journal of Basic and Applied Scientific Research.

Hashim, A., Khan, T. K. A., Abd Karim, Z., \& Rahim, N. A. (2019). Attribute Assessment Instrument on Information Management and Lifelong Learning Skills among UPSI Students in Faculty of Sports Science and Coaching. International Journal of Academic Research in Business and Social Sciences, 9(2).

Hossain, M. I., Yagamaran, K. S. A., Arifin, T., Limon, N., Nasiruzzaman M., Karim, A. M. (2018). Factors Influencing Unemployment among Fresh Graduates: A Case Study in Klang Valley, Malaysia. International Journal of Academic Research in Business \& Social Sciences, 14941507.

Ilhamie, A. G. A., Rosmawani, C. H., \& Yusmini, M. Y. (2018). The Employability Skills of Malaysian University Students. International Journal of Modern Trends in Social Sciences.

Konting, M. M. (2005). Penyelidikan pendidikan. Kuala Lumpur: Dewan Bahasa Pustaka.

Latif, A. A., \& Hanifah, A. B. A. (2008). Penguasaan Dan Penggunaan Bahasa Inggeris Dalam Kalangan Pelajarpelajar PKPG Kemahiran Hidup Universiti Teknologi Malaysia. Penguasaan Dan Penggunaan Bahasa Inggeris Dalam Kalangan Pelajarpelajar PKPG Kemahiran Hidup Universiti Teknologi Malaysia . pp. 1-13. (Unpublished)

Zain, M. R. (2017). UiTM ke-158 terbaik di Asia. BH Online. Retrieved October 7, 2019, from. https://www.bharian.com.my/berita/pendidikan/2017/10/338407/uitm-ke-158-terbaikdi-asia

Minten, S., \& Forsyth, J. (2014). The careers of sports graduates: Implications for employability strategies in higher education sports courses. Journal of Hospitality, Leisure, Sport \& Tourism Education, 15, 94-102.

Mishra, K. (2014). Employability skills that recruiters demand. IUP Journal of Soft Skills, 8(3), 50. Mustapha, N. S., Ahmad, S. A., Jamil, N., \& Mustapha, F. (2015). Faktor-Faktor Penggunaan Bahasa Inggeris Dalam Kalangan Pelajar Semester Akhir Politeknik Kota Bharu. Quality Time 
INTERNATIONAL JOURNAL OF ACADEMIC RESEARCH IN PROGRESSIVE EDUCATION AND

DEVELOPMENT

Vol. 10, No. 1, 2021, E-ISSN: 2226-6348 @ 2021 HRMARS

Prosiding Seminar Setiausaha-Setiausaha \&Pembangunan Pengurusan Kualiti Politeknik Malaysia 2015.1, 150

Saidon, R. (2017). Faktor Kepimpinan dan Gender dalam Penglibatan Politik Wanita di Malaysia. pp. 61-73.

Sarkar, M., Overton, T., Thompson, C., \& Rayner, G. (2016). Graduate employability: Views of recent science graduates and employers. International Journal of Innovation in Science and Mathematics Education (formerly CAL-laborate International), 24(3).

Shivoro, R. S., Shalyefu, R. K., \& Kadhila, N. (2018). Perspectives on graduate employability attributes for management sciences graduates. South African Journal of Higher Education, 32(1), 216-232.

Singh, G. K. G., \& Singh, S. K. G. (2008). Malaysian graduates' employability skills. UNITAR eJournal, 4(1), 15-45.

Singh, P., Thambusamy, R., Ramly, A., Abdullah, I. H., \& Mahmud, Z. (2013). Perception differential between employers and instructors on the importance of employability skills. Procedia-Social and Behavioral Sciences, 90, 616-625.

Sumanasiri, E. G. T., Yajid, M. S. A., \& Khatibi, A. (2015). Review of literature on graduate employability. Journal of Studies in Education, 5(3), 75-88.

Tanius, E. (2018). Employability Skills-A Study on The Perception of Business Students Graduate and Employers in Malaysia. Asia Pacific Journal of Research in Business Management, 9(1).

Tartre, L. A. (1993) Spatial skills, Gender, and Mathematics. In E. Fennema and G. C. Leder (eds.) Mathematics and Gender. Brisbane: University of Queensland Press.

Tee, L., Ferns, S., \& Hughes, D. J. (2018). The capabilities that count for early professional success in Pharmacy: A case study of graduates, employer ad course team perspectives. Journal of Teaching and Learning for Graduate Employability, 23 - 40.

Tomlinson, M. (2018). Employers and Universities: conceptual dimensions, research evidence and implications. Higher Education Policy, 1-23.

Walqui, A. (2000). Access and Engagement: Program Design and Instructional Approaches for Immigrant Students in Secondary School. Topics in Immigrant Education 4. Language in Education: Theory and Practice 94. Delta Systems Co., Inc., 1400 Miller Pkwy., McHenry, IL 60050-7030. 